\title{
NBSIR 85-3292
}

\section{Release Notes for STAT2 Version 2.00A: An Addendum to NBS Special Publication 400-75}

C. H. Ellenwood and R. L. Mattis

\section{U.S. DEPARTMENT OF COMMERCE National Bureau of Standards National Engineering Laboratory Center for Electronics and Electrical Engineering Semiconductor Electronics Division Gaithersburg, MD 20899}

January 1986

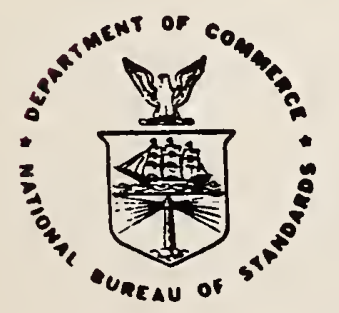

$-Q C$ ARTMENT OF COMMERCE

100 BUREAU OF STANDARDS

.456

$85-3292$

1986

C. 3 

NBSIR 85-3292

RELEASE NOTES FOR STAT2 VERSION 2.00A:

AN ADDENDUM TO NBS SPECIAL

PUBLICATION 400-75

C. H. Ellenwood and R. L. Mattis

U.S. DEPARTMENT OF COMMERCE

National Bureau of Standards

National Engineering Laboratory

Center for Electronics and Electrical Engineering

Semiconductor Electronics Division

Gaithersburg, MD 20899

January 1986

U.S. DEPARTMENT OF COMMERCE, Malcolm Baldrige, Secretary NATIONAL BUREAU OF STANDARDS. Ernest Ambler, Director 

Release Notes for STAT2 Version 2.00A:

An Addendum to NBS Special Publication 400-75

Page

Abstract .......................... 1

Disclaimer . . . . . . . . . . . . . . . . . 1

1. Introduction . . . . . . . . . . . . . . . . . . . 1

2. Program Capabilities . . . . . . . . . . . . . . . . . 2

3. Logical Unit Assignments . . . . . . . . . . . . . . . . . . . 3

4. Program Installation . . . . . . . . . . . . . . . . . . 3

Acknowledgments . . . . . . . . . . . . . . . . . 4

References ..................... . . 4

Appendix I. Source Listing of PCFG Program . . . . . . . . . . . . . 5

Appendix II. Sample Run of PCFG Program . . . . . . . . . . . . . . . . . . 12

Appendix III. STAT2 Version 2.00A Commands . . . . . . . . . . . . . . 13 



\author{
Release Notes for STAT2 Version 2.00A: \\ An Addendum to NBS Special Publication 400-75 \\ C. H. Ellenwood and R. L. Mattis \\ Semiconductor Electronics Division \\ National Bureau of Standards \\ Gaithersburg, MD 20899
}

\begin{abstract}
STAT2 is a FORTRAN program which is used to analyze and display data from microelectronic test structures fabricated on semiconductor wafers. The program reads data as a two-dimensional array, extracts sample statistical values, identifies outliers, calculates replacement values for outliers, and makes histograms and circular gray-tone data maps. Version $2.00 \mathrm{~A}$ is an adaptation of STAT2 to run under Version 3.2 of the RSX-11M operating system. This operating system is used on the automatic tester which acquires the test structure data. Data can therefore be taken and analyzed on the same system.
\end{abstract}

Key Words: ATE; computer program; outlier; process validation wafer; statistical analysis; two-dimensional map; wafer map.

\title{
Disclaimer
}

Certain commercial equipment, instruments, or materials are identified in this report in order to adequately specify the experimental procedure. In no case does such identification imply recommendation or endorsement by the National Bureau of Standards, nor does it imply that the material or equipment identified is necessarily the best available for the purpose.

\section{Introduction}

This document describes the changes that were made to the STAT2 computer program documented in NBS Special Publication 400-75, Semiconductor Measurement Technology: A FORTRAN Program for Analysis of Data from Microelectronic Test Structures [1] and NBSIR 83-2779, Release Notes for STAT2 Version 1.31: An Addendum to NBS Special Publication 400-75 [2]. The changes were made in order to make STAT2 run under Version 3.2 of the RSX-11/M operating system. The referenced publications are to be used as the program manuals, for this document contains no review of STAT2 features or operation. Data base structure, functional fits, and the help facility are not included in this version of STAT2. This version was designed to contain the essential commands for statistical analysis of data taken on an Accutest 3000 automatic tester. The gray-tone map produced by the MP4 command is written specifically for a Printronix P300 or P600 line printer/plotter. 


\section{Program Capabilities}

The STAT2 ASG and REA commands are used for reading input. Format 4 of the REA command is the only acceptable format which can be used with this version. Any other formats will give the error message "*** FORMAT TYPE MUST BE 4." The .SAD file asked for by the REA command is a file which gives the STEND array and the row-column coordinate locations of all untested sites within the region defined by the STEND array. This .SAD file is made using a stand-alone program called PCFG. A listing of PCFG is included in Appendix I. PCFG is a Pascal program which prompts the user for the beginning and ending columns of chips on each row of the wafer. It about the locations of the untested sites on the wafer and uses this information to generate the needed .SAD file. This program also generates the .PDF file and the .PID file which are needed to run a test plan on the automatic tester. A sample run of the PCFG program is shown in Appendix II.

PRS, DIS, LAP, LIP, and LNS, which give statistical information about the data, are available in version $2.00 \mathrm{~A}$. Also available are XOL, XPP, XNS, XGT, XLT, XIP, LXP, IIP, and RES, which deal with test site exclusion, as well as AXP and AIP which deal with data value replacement.

To meet the need to analyze small sample sizes, a new command, XSS (for exclude small sample), has been added to STAT2 which can be used to identify and exclude outliers when the number of included sites is in the range 3 to 25 , inclusive. The format of the command is "XSS P1" where P1 represents the probability that one or more good sites might be excluded along with the outliers. P1 may be given values of $0.6,0.4,0.2,0.1$, $0.04,0.02$, or 0.01 ; however, the value of 0.2 was found to be reasonable for most data sets. Other values produce an error message.

The algorithm for the XSS command employs the Dixon test [3]. For this test, data values are first sorted and then tests are made on the extreme values. If one of the extreme values is excluded, a second examination is made based on the new extreme values. This process continues until no more values are excluded. Conceivably, with a sample size of only 3 or 4 , XSS may exclude one or two sites, leaving fewer than the minimum three sites required. XSS will automatically calculate and print statistics upon completion. A typical command sequence might be as follows:

$\begin{array}{ll}\text { ASG FILE.DAT } & \text { ! Assign input data file. } \\ \text { REA 4 15 } & \text { ! Read in the desired data set. } \\ \text { FILE.SAD } & \text { ! Specify .SAD file } \\ \text { XGT 1E10 } & \text { ! Exclude values which are } \\ \text { XLT 0 } & \text { ! known to be bad data or } \\ \text { XIP 16 } & \text { ! to have physical defects. } \\ \text { XSS } 0.2 & \text { ! Invoke XSS. } \\ \text { END } & \text { ! End of this example. }\end{array}$

Additional information concerning the XSS command is contained in the introductory 
comments to subroutine XSS in the source code.

The PLT, HIS, and MP4 commands are available to produce various types of data displays. The PLT command differs from previous versions in that the display is written to the STAT2.LOG file as well as to the terminal. The MP4 command differs from previous versions in that parameter $\mathrm{P} 4$, previously used to optionally specify the format of the map key, no longer performs that function. P4 must still be present; but regardless of its value, the numbers in the key print in F10.5 or E12.5 format depending on their magnitude.

Miscellaneous commands such as END, PAU, ERM, REM, and MAC still function as under previous versions.

The features which are not included in Version 2.00A are commands for functional fits, data base commands and the help facility. These commands give the error message "*** COMMAND NOT AVAILABLE" if entered. (These commands are still subjected to syntax checking even though they are not implemented.)

A list of commands which are available in Version $2.00 \mathrm{~A}$ along with a brief description is given in Appendix III.

\section{Logical Unit Assignments}

The logical unit assignments used by STAT2 Version $2.00 \mathrm{~A}$ along with a description are given below.

1 - Input data file

2 - Macro command file

3 - .SAD file

4 - STAT2.LOG file

5 - Command input

6 - Command echoes and error messages

7 - Scratch file used by the MP4 command

\section{Program Installation}

For STAT2 to run under the RSX-11/M operating system, it was necessary to divide the program into overlays. The code sections of STAT2 are: (1) ST2MAIN.FTN, (2) ST2OV1.FTN, (3) ST2OV2.FTN, (4) ST2OV3.FTN, and (5) ST2OV4.FTN. The code sections are compiled separately, and the task is built to form one program unit. The program requires approximately $30 \mathrm{~KB}$ of memory.

The main segment, ST2MAIN, contains the command interpreter, program initialization, and several subroutines that are needed by the program code in more than one overlay. The subroutines relating to the ASG, REA, MAC, and HIS commands are contained in ST2OV1. ST2OV2 includes subroutines relating to the test site exclusion and statistical calculations. ST2OV3 contains subroutines relating to the calculation and specification of replacement values for outliers. The subroutines relating to the PLT and MP4 commands are contained in ST2OV4. 
ST2ACCU1.TKB is a task-building command file called by typing:

TKB @ST2ACCU1.TKB

The .TKB file consists of the following commands:

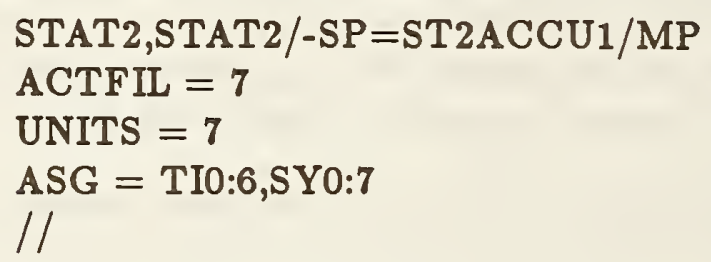

The first line of the .TKB file contains the output filenames and the name of the .ODL file. ST2ACCU1.ODL contains the names of the files needed by the task builder and defines the overlay structure. The form of ST2ACCU1.ODL is as follows, where LIBRARY.LIB represents a FORTRAN object library:

$\begin{array}{lll}\text { 01: } & \text {.FCTR } & \text { ST2OV1-LIBRARY.LIB/LB } \\ \text { 02: } & \text {.FCTR } & \text { ST2OV2-LIBRARY.LIB/LB } \\ \text { 03: } & \text {.FCTR } & \text { ST2OV3-LIBRARY.LIB/LB } \\ \text { 04: } & \text {.FCTR } & \text { ST2OV4-LIBRARY.LIB/LB } \\ \text { RT: } & \text {.FCTR } & \text { ST2MAIN-LIBRARY.LIB/LB }\end{array}$

.ROOT RT-* $(01,02,03,04)$

.END

The ACTFIL option in the .TKB file declares the number of files that are simultaneously open in a task and the UNITS option declares the number of logical units that are used by the task. The ASG option makes the appropriate logical unit assignments.

\section{Acknowledgments}

The authors are indebted to Ruth Zucker for writing the PCFG program and to Loren W. Linholm for careful reading and helpful suggestions regarding the manuscript. The manuscript was prepared with proficiency by E. Jane Walters.

\section{References}

1. Mattis, R. L., Semiconductor Measurement Technology: A FORTRAN program for Analysis of Data from Microelectronic Test Structures, NBS Special Publication 40075 (July 1983).

2. Mattis, R. L. and Zucker, R., Release Notes for STAT2 Version 1.31: An Addendum to NBS Special Publication 400-75, NBSIR 83-2779 (November 1983).

3. Natrella, M. G., Experimental Statistics, NBS Handbook 91, pp.17-3 and T-27 (Reprinted October 1966). 
PROGRAM PCFG (INPUT, OUTPUT, PIDFILE, EXTFILE, PDFFILE);

(* CREATE A PROBER IDENTIFICATION AND DESCRIPTION FILE, .PID, .SAD AND .PDF*)

(**** REVISED FEBRUARY $1983 * * * *)$

LABEL $\quad 100,250,300,350,400,500,600,700,800,900$;

CONST LSTEN=32;

NDROPS $=20$;

$\mathrm{ONE}=1$;

ZERO=0;

VAR DROWS, DCOLS : INTEGER;

FLAG , I , IA , I1 , I2 , J , JA , K, KL , LDROPS, LASTCOL : INTEGER;

LOCATION , N , NCHAR, NCOLS, NROWS , NTEMP , NUMBER : INTEGER;

$\mathrm{L}, \mathrm{TALLY}, \mathrm{X}$ : INTEGER;

RTEMP : REAL;

DROPS:ARRAY [1.20] OF ARRAY $[1, .2]$ OF INTEGER;

DIESIZE : ARRAY [1..2] OF INTEGER;

RDIE:ARRAY [1..2] OF REAL;

RREF : ARRAY [1..2] OF REAL;

REFERENCE : ARRAY [1.2] OF INTEGER;

COMPDROPS : ARRAY [1..20] OF ARRAY [1..2] OF INTEGER;

STEND : ARRAY [1..32] OF ARRAY [1..2] OF INTEGER;

XLOC:ARRAY [1..1024] OF INTEGER;

YLOC:ARRAY [1..1024] OF INTEGER;

RXLOC:ARRAY [1..1024] OF REAL;

RYLOC:ARRAY [1..1024] OF REAL;

NAMEPID :PACKED ARRAY [1.20] OF CHAR;

NAMEEXT:PACKED ARRAY [1..20] OF CHAR;

NAMEPDF:PACKED ARRAY [1..20] OF CHAR;

FILENAME:PACKED ARRAY [1..9] OF CHAR;

PIDEXT, SADEXT,PDFEXT,DISKNAME:PACKED ARRAY[1..4] OF CHAR;

BLANK : CHAR;

PIDFILE, EXTFILE, PDFFILE : TEXT;

PROCEDURE PRINTINFO;

BEGIN

HRITELN (' NROWS=', NROWS:3, ' NCOLS=', NCOLS:3);

WRITELN ('DIE SIZE=', DIESIZE [1]:5, DIESIZE [2]:5);

WRITELN ('REFERENCE=', REFERENCE [1] :5, REFERENCE [2] :5);

WRITELN;

WRITELN (' I', ', STEND $[I, 1]^{\prime},{ }^{\prime}, \quad \operatorname{STEND}[I, 2]$ ');

FOR I $:=1$ TO NROWS DO

BEGIN END;

WRITELN $(I: 5, \operatorname{STEND}[I, 1]: 10, \operatorname{STEND}[I, 2]: 10)$

WRITELN;

WRITELN (' DROP-IN LOCATIONS ');

WRITELN (' NO.', ' ROW', ' COLUMN');

FOR I $:=1$ TO LDROPS DO

BEGIN

WRITELN (I:5,DROPS $[I, 1]: 10, \operatorname{DROPS}[I, 2]: 10)$ 
END;

END;

PROCEDURE FILEPID (VAR F1,F2,F3 : TEXT);

BEGIN

REWRITE (F1, NAMEPID);

WRITELN (F1,' IDENTIFICATION, 1034XD');

WRITELN (F1，' DIE', DIESIZE [1],DIESIZE [2]);

WRITELN (F1,' REFERENCE', REFERENCE [1], REFERENCE [2]);

NUMBER := LOCATION;

WRITELN (F1,' NUMBER', NUNBER);

WRITELN (F1, ' END');

FOR I := 1 TO NUMBER DO

BEGIN END;

WRITELN (F1,' LOCATION',I, XLOC [I] , YLOC [I] )

WRITELN (F1,' END');

CLOSE (F1);

REWRITE (F2, NAMEEXT);

FOR I $:=1$ TO NROWS DO

BEGIN

END;

WRITELN (F2, STEND $[I, 1], \operatorname{STEND}[I, 2])$

WRITELN (F2, ZERO, ZERO);

IF (LDROPS > 0) THEN

BEGIN

FOR $I:=1$ TO LDROPS DO

BEGIN

END;

WRITELN (F2,DROPS $[I, 1]$, DROPS $[I, 2])$

END;

WRITELN (F2, ZERO, ZERO);

CLOSE (F2);

REWRITE (F3, NAMEPDF);

WRITELN (F3, ' 1034XD');

$\operatorname{RDIE}[1]:=$ DIESIZE [1] ;

RDIE [2] := DIESIZE [2];

RREF [1] := REFERENCE [1] ;

RREF [2] := REFERENCE [2];

RTEMP := ZERO;

NTEMP : = ZERO;

FOR $I:=1$ TO NUMBER DO

BEGIN

$\operatorname{RXLOC}[\mathrm{I}]:=\mathrm{XLOC}[\mathrm{I}]$

END;

$\operatorname{RYLOC}[\mathrm{I}]:=\mathrm{YLOC}[\mathrm{I}]$

WRITELN (F3, ONE: 14, NUMBER :5, RDIE [1] $7: 0, \operatorname{RDIE}[2]: 7: 0$, $\operatorname{RREF}[1]: 7: 0, \operatorname{RREF}[2]: 7: 0)$;

WRITELN (F3 , ZERO : 14, RTEMP: 13, RTEMP: 13, RTEMP: 13);

FOR $I:=1$ TO NUMBER DO

BEGIN END;

WRITELN (F3,I:14, RXLOC $[\mathrm{I}]: 7: 0$, RYLOC $[\mathrm{I}]: 7: 0)$ END;

CLOSE (F3); 


\section{BEGIN}

\section{BLANK : = ' '; \\ PIDEXT: $={ }^{\prime}$.PID'; \\ SADEXT: $='$.SAD'; \\ PDFEXT: ='.PDF'; \\ DISKNAYE : = 'FW2:';}

WRITELN(' ENTER DIE SIZE, 2 INTEGERS IN MACHINE UNITS');

WRITELN (' X(=WIDTH), Y(=EEIGHT) ') ;

READLN (DIESIZE [1], DIESIZE [2]);

WRITELN (' ENTER REFERENCE DIE POSITION, (COLURN, ROW), 2 INTEGERS');

READLN (REFERENCE [1], REFERENCE [2]);

WRITELN (' ENTER STEND $[I, 1]$, STEND $[I, 2], 2$ INTEGERS PER LINE');

WRITELN (' TYPE 0 O TO END INPUT TO STEND ARRAY');

$$
I:=1
$$

100:

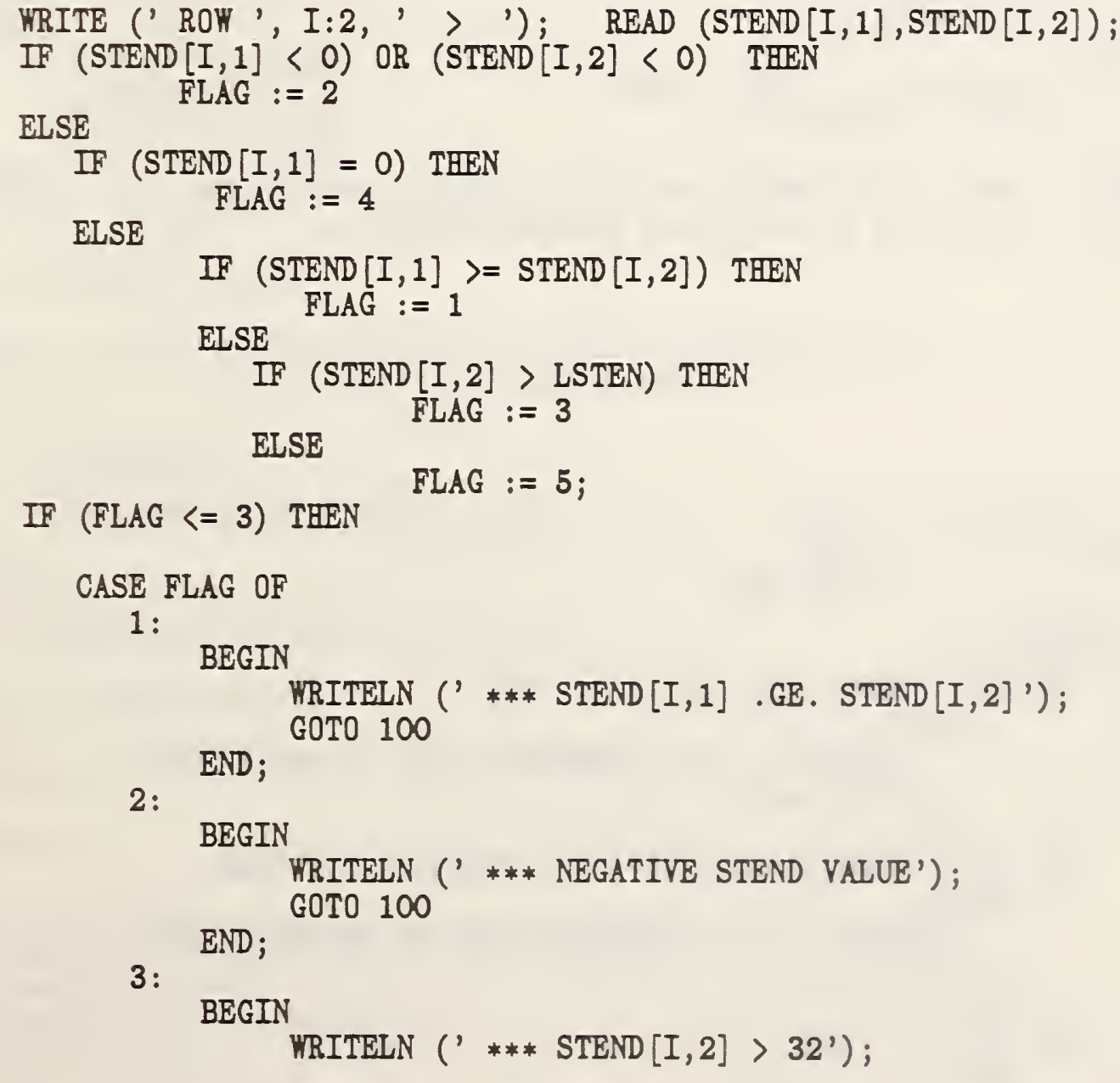




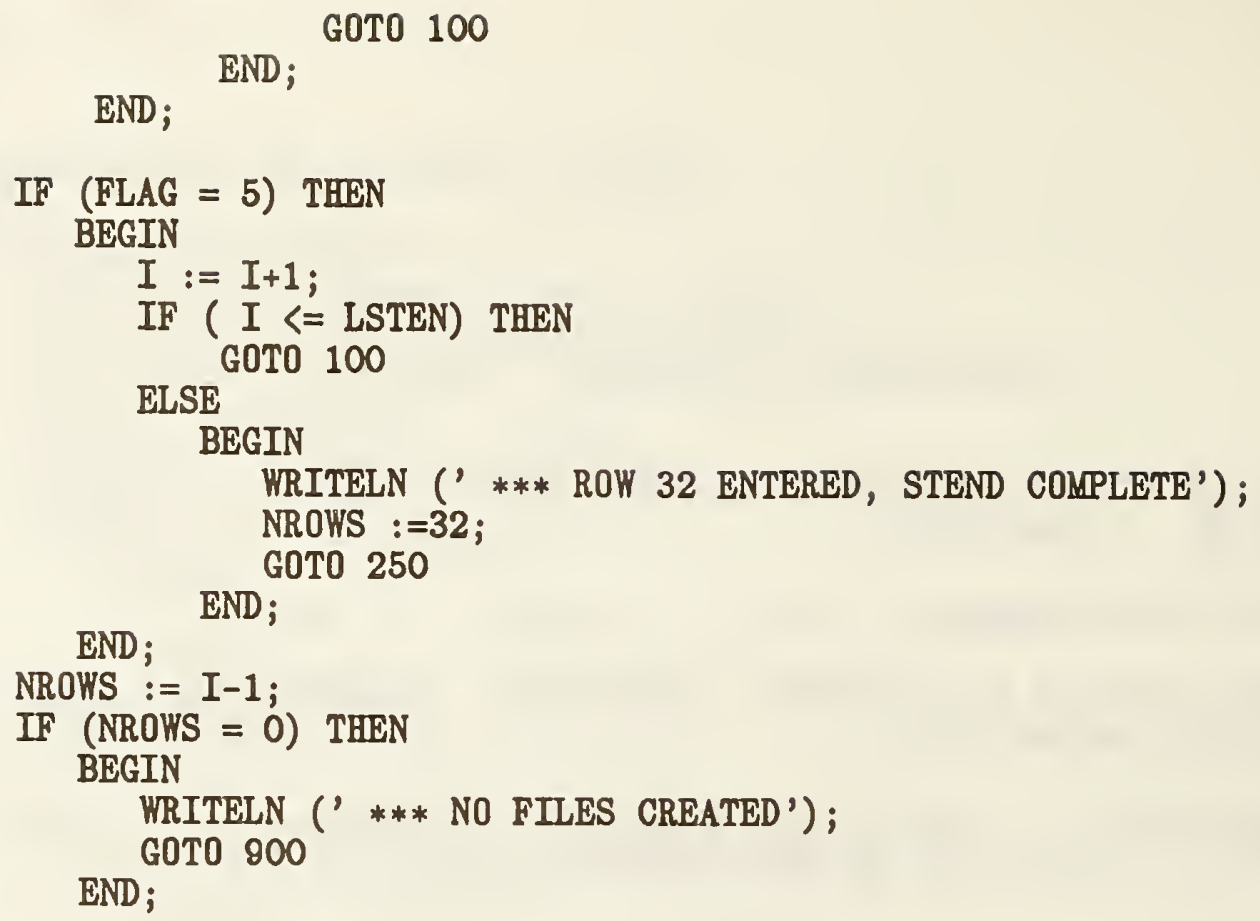

250:

NCOLS : $=0$;

FOR I $:=1$ TO NROWS DO

BEGIN

IF (STEND $[I, 2]>$ NCOLS) THEN

NCOLS $:=\operatorname{STEND}[I, 2]$

END;

WRITELN (' ENTER COORDINATES OF DROP-IN SITES, (COLUMN, ROW), 2 INTEGERS PER LINE');

WRITELN (' TYPE 0 O TO END INPUT TO DROPS ARRAY');

I : = 1;

300:

WRITE (' DROP-IN ', I:2, '> '); READ (DROPS [I, 2], DROPS $[I, 1]$ );

IF (DROPS $[I, 2]=0)$ THEN

$\mathrm{IA}:=\operatorname{DROPS}[\mathrm{I}, 1]$;

JA $:=$ DROPS $[I, 2]$

IF (IA > NROWS) OR (IA < O) THEN

BEGIN

WRITELN ('*** INCORRECT DROP IN ROW VALUE');

GOTO 300

END;

IF (JA < STEND $[I A, 1])$ OR (JA > STEND [IA, 2]) THEN BEGIN

WRITELN (' $* * *$ INCORRECT DROP-IN COLUMN VALUE'); GOTO 300

END;

IF $(I=1)$ THEN

BEGIN 


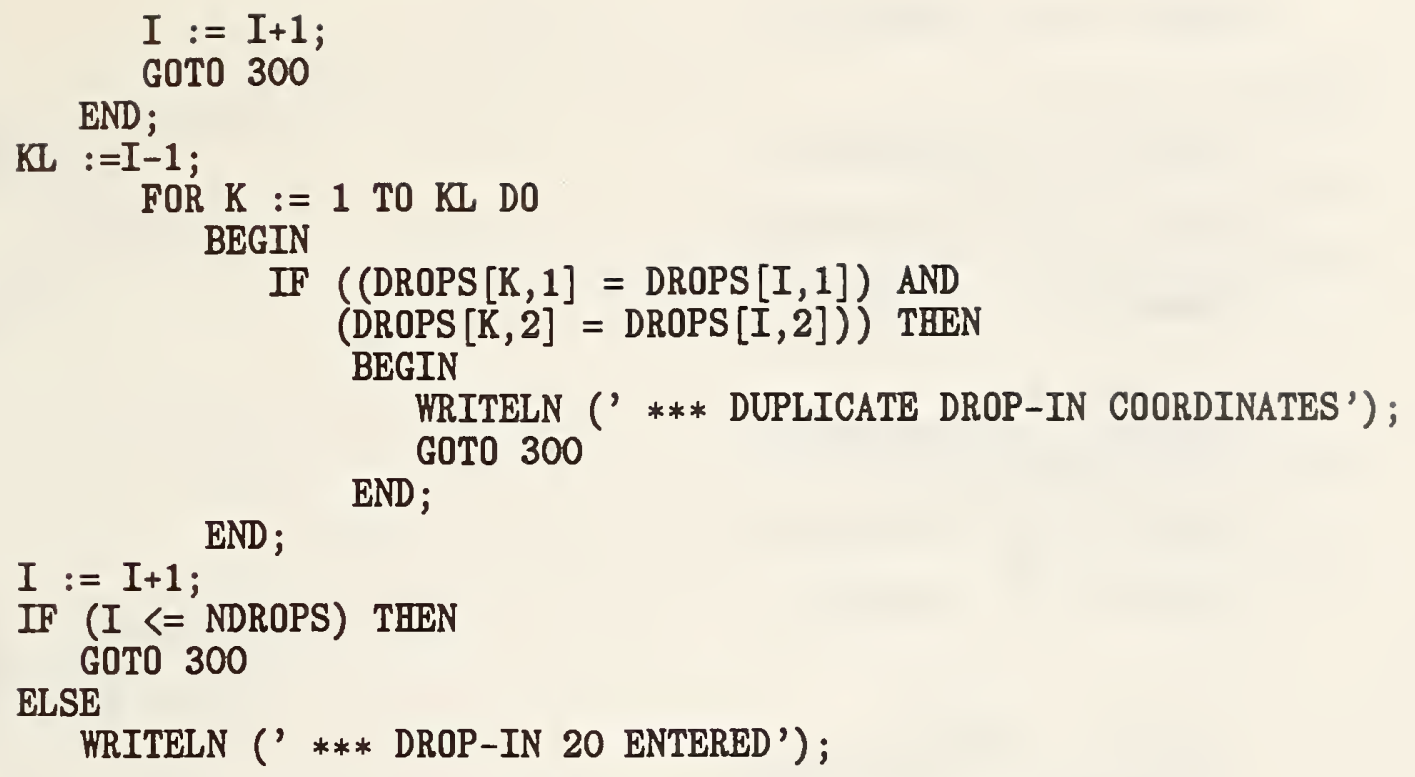

FOR I: $=1$ TO N DO

FILENAME $[\mathrm{I}]:=\mathrm{BLANK}$;

WRITELN (' ENTER FILENAME ONLY ( 8 OR LESS CHARACTERS) FOR');

WRITELN (' .PID, .PDF, AND .SAD FILES');

READLN (FILENAME);

$I:=0$;

REPEAT

$$
\mathrm{I}:=\mathrm{I}+1
$$

UNTIL (FILENAME [I]=BLANK) OR $(I=N)$;

IF $(I<N)$ TEEN NCBAR: $=I-1$

ELSE

$$
\text { NCHAR : }=I \text {; }
$$

$\mathrm{L}:=\mathrm{NCHAR}+4$;

FOR I: $=1$ TO 4 DO NAMEPID $[\mathrm{I}]:=\mathrm{DISKNAME}[\mathrm{I}]$;

FOR $I:=1$ TO NCHAR DO NAMEPID $[I+4]:=$ FILENAME $[I]$;

FOR I: $=1$ TO 4 DO 
NAMEPID $[\mathrm{I}+\mathrm{L}]:=\mathrm{PIDEXT}[\mathrm{I}]$;

FOR I: $=1$ TO 4 DO

NAMEEXT $[\mathrm{I}]:=$ DISKNAME $[\mathrm{I}]$;

FOR I:=1 TO NCHAR DO

NAMEEXT $[I+4]:=$ FILENAME $[I]$;

FOR $I:=1$ TO 4 DO

NAMEEXT $[I+L]:=$ SADEXT $[I]$;

FOR I:=1 TO 4 DO

NAMEPDF $[I]:=\operatorname{DISKNAME~}[\mathrm{I}]$;

FOR I: $=1$ TO NCHAR DO

NAMEPDF $[I+4]:=$ FILENAME [I] ;

FOR $I:=1$ TO 4 DO

NAMEPDF $[I+L]:=\operatorname{PDFEXT}[\mathrm{I}]$;

TALLY := LDROPS;

FOR $K:=1$ TO TALLY DO

BEGIN

END;

COMPDROPS $[\mathrm{K}, 1]:=\operatorname{DROPS}[\mathrm{K}, 1]$;

COMPDROPS $[\mathrm{K}, 2]:=\operatorname{DROPS}[\mathrm{K}, 2]$

LOCATION $:=0$;

$\mathrm{I}:=1$;

400:

$\mathrm{X}:=\operatorname{STEND}[\mathrm{I}, 1]$;

LASTCOL := STEND $[I, 2]$;

500 :

IF (TALLY $=0$ ) THEN

GOTO 700

ELSE

$\mathrm{K}:=1$;

600:

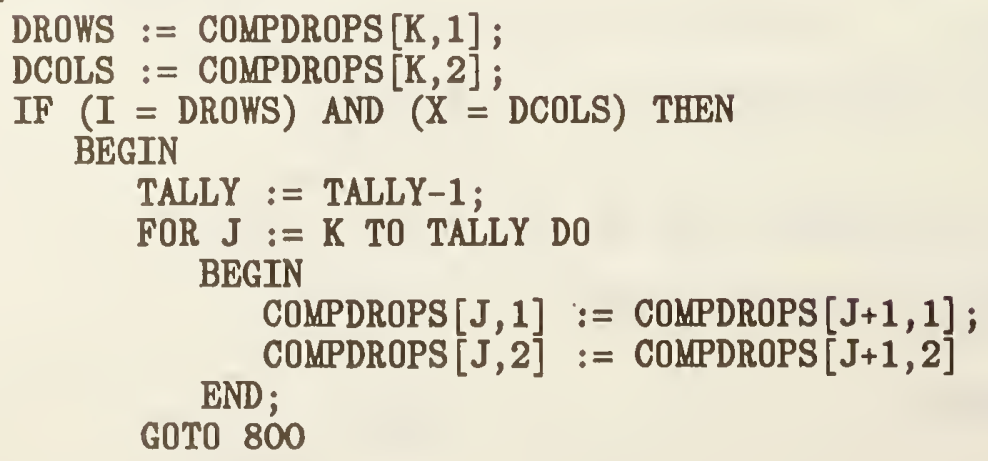


END

ELSE

IF $(K<$ TALLY) THEN

BEGIN

$\mathrm{K}:=\mathrm{K}+1$;

GOT0 600

END

ELSE

700 :

LOCATION := LOCATION +1 ;

YLOC [LOCATION] := I;

XLOC[LOCATION] := X;

800:

IF $(\mathrm{X}<\mathrm{LASTCOL})$ THEN

BEGIN

$$
\mathrm{X}:=\mathrm{X}+1
$$

END

ELSE

IF ( I< NROWS) THEN

BEGIN

$$
\mathrm{I}:=\mathrm{I}+1
$$

GOTO 400

END

ELSE

900:

FILEPID (PIDFILE, EXTFILE, PDFFILE);

END. 
$>$ RUN PCFG

ENTER DIE SIZE, 2 INTEGERS IN MACHINE UNITS

$\mathrm{X}(=$ WIDTH $), \quad \mathrm{Y}(=\mathrm{HEIGHT})$

54305430

ENTER REFERENCE DIE POSITION, (COLUMN, ROW), 2 INTEGERS

41

ENTER STEND $[I, 1]$, STEND $[I, 2], 2$ INTEGERS PER LINE

TYPE 00 TO END INPUT TO STEND ARRAY

ROW $1>410$

ROW $2>112$

ROW $3>112$

ROW $4>410$

ROW $5>00$

ENTER COORDINATES OF DROP-IN SITES, (COLUMN, ROW), 2 INTEGERS PER LINE TYPE 0 O TO END INPUT TO DROPS ARRAY

DROP-IN $1>00$

NROWS $=4$ NCOLS $=12$

DIE SIZE $=54305430$

REFERENCE $=41$

$\begin{array}{ccc}I & \text { STEND }[I, 1] & \text { STEND }[I, 2] \\ 1 & 4 & 10 \\ 2 & 1 & 12 \\ 3 & 1 & 12 \\ 4 & 4 & 10\end{array}$

ROW LOCATIONS

ENTER FILENAME ONLY (9 OR LESS CHARACTERS) FOR

SAMPLE

.PID, .PDF, AND .SAD FILES

$>$ 
Appendix III

Stat2 Version 2.00A Commands

Following is an alphabetical list of legal commands for Version 2.00A:

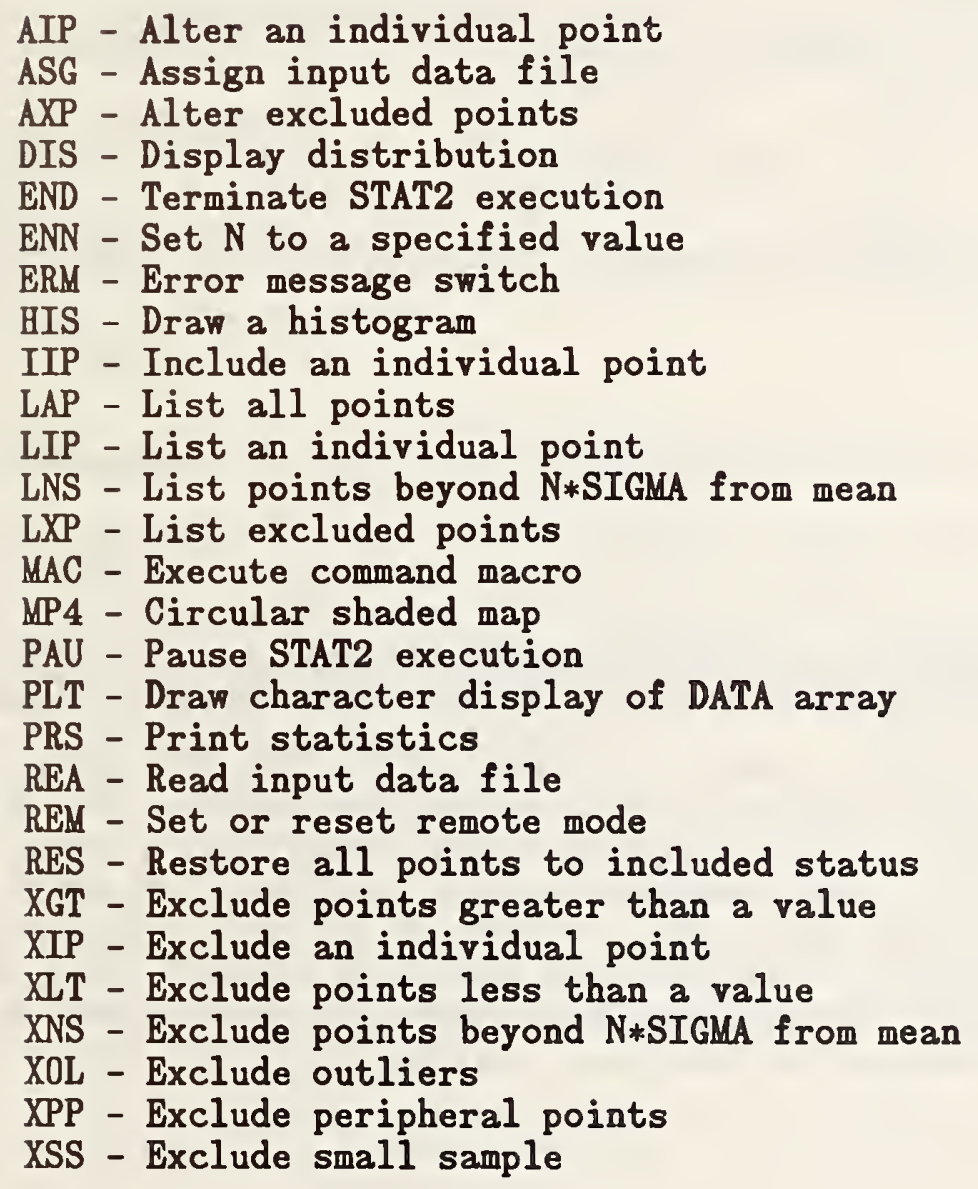


NBS-114A (REV. 2-80)

BIBLIOGRAPHIC DATA

SHEET (See instructions)

1. PUB! ICATION OR
REPURT NO.
NBSIR $85 / 3292$

4. TITLE AND SUBTITLE

Release Notes for STAT2 Version 2.00A: An Addendum to NBS Special Pub1ication 400-75

5. $\operatorname{AUTHOR}(S)$

C. H. Ellenwood and R. I. Mattis

6. PERFORMING ORGANIZATION (If jolnt or other than NBS, see instructions)

7. Contract/Grant No.

NATIONAL BUREAU OF STANDARDS

DEPARTMENT OF COMMERCE

8. Type of Report \& Period Covered

WASHINGTON, D.C. 20234

9. SPONSORING ORGANIZATION NAME AND COMPLETE ADDRESS (Street, City. State, ZIP)

10. SUPPLEMENTARY NOTES

Document describes a computer program; SF-185, FIPS Software Summary, is attached.

11. ABSTRACT (A 200-word or less factual summary of most significant information. If document includes a significant bibliography or literature survey, mention it here)

STAT2 is a FORTRAN program which is used to analyze and display data from microelectronic test structures fabricated on semiconductor wafers. The program reads data as a two-dimensional array, extracts sample statistical values, identifies outliers, calculates replacement values for outliers, and makes histograms and circular gray-tone data maps. Version 2.00A is an adaptation of STAT2 to run under Version 3.2 of the RSX-11M operating system. This operating system is used on the automatic tester which acquires the test structure data. Data can then be taken and analyzed on the same system.

12. KEY WORDS (Six to twelve entries; alphabetical order; copitalize only proper names; and separate key words by semicolons) ATE; computer program; outlier; process validation wafer; statistical analysis; two-dimensional map; wafer map

13. AVAILABILITY

[X] Unimited

For Official Distribution. Do Not Release to NTIS

$\square$ Order From Superintendent of Documents, U.S. Government Printing Office, Washington, D.C. 20402.

14. NO. OF PRINTED PAGES

Order From National Technical Information Service (NTIS), Springfleld, VA, 22161

18

15. Price

$\$ 9.95$ 


\section{FEDERAL INFORMATION PROCESSING STANDARD SOFTWARE SUMMARY}

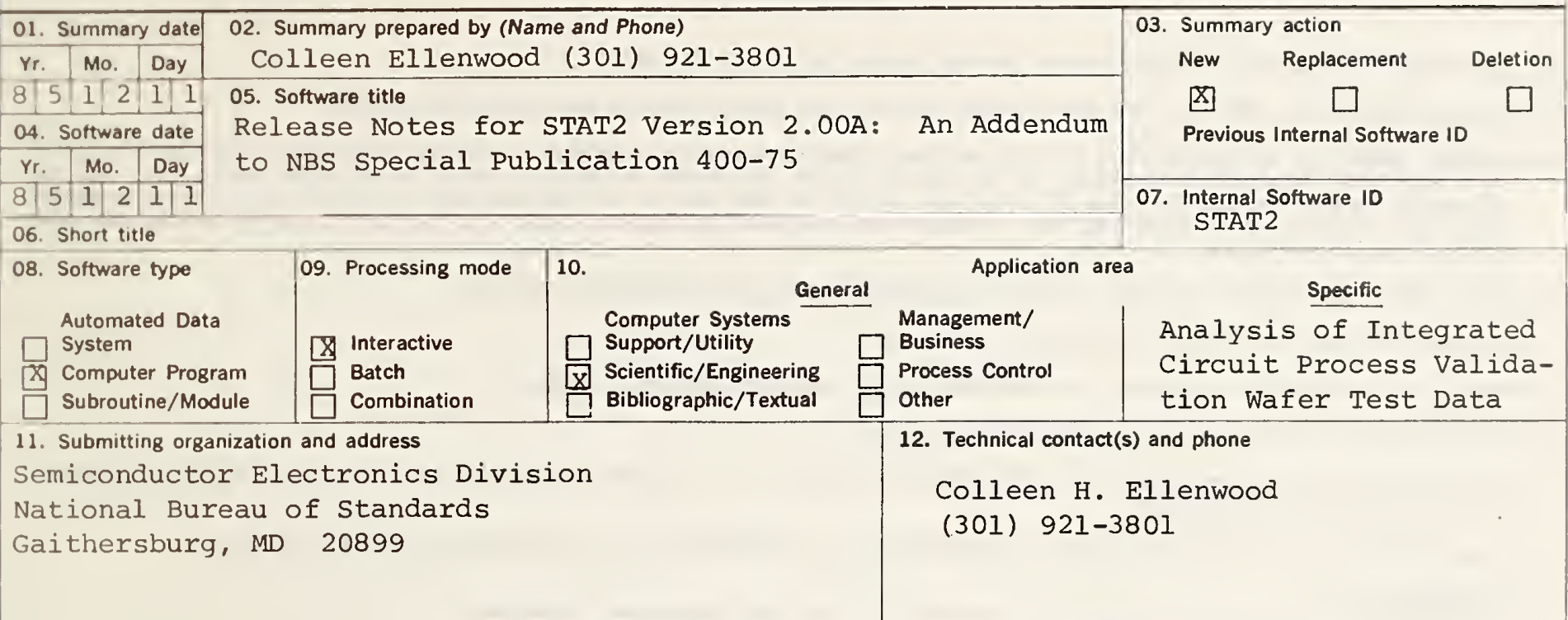

13. Narrative

The program reads data as a two-dimensional array, extracts sample statistical values, identifies outliers, calculates replacement values for outliers, and makes histograms and circular gray-tone data maps. Version $2.00 \mathrm{~A}$ is an adaptation of STAT2 to run under Version 3.2 of the RSX-11M operating system. This operating system is used on the automatic tester which acquires the test structure data. Data can therefore be taken and analyzed on the same system.

14. Keywords

ATE; computer program; outlier; process validation wafer; statistical analysis;

two-dimensional map; wafer map

\begin{tabular}{|l|l|l|l|}
\hline $\begin{array}{l}\text { 15. Computer manuf'r and model } \\
\text { DEC LSI } 11 / 23\end{array}$ & $\begin{array}{c}\text { 16. Computer operating system } \\
\text { RSX-1IM } 3.2\end{array}$ & $\begin{array}{l}\text { 17. Programing language(s) } \\
\text { FORTRAN }\end{array}$ & $\begin{array}{c}\text { 18. Number of source program state- } \\
\text { ments } \\
6364\end{array}$ \\
\hline $\begin{array}{l}\text { 19. Computer memory requirements } \\
30 \mathrm{kB}\end{array}$ & $\begin{array}{c}\text { 20. Tape drives } \\
\text { None }\end{array}$ & $\begin{array}{l}\text { 21. Disk/Drum units Disk } \\
\text { needed for map scratch } \\
\text { file, data input }\end{array}$ & $\begin{array}{c}\text { 22. Terminals } \\
\text { video or hard copy }\end{array}$ \\
\hline
\end{tabular}

23. Other operational requirements

24. Software availability

\begin{tabular}{ccc} 
Available & Limited \\
\hline & $\square$
\end{tabular}
25. Documentation availability

$\begin{array}{ccc}\text { Available } & \text { Inadequate } & \text { In house only } \\ \square & \square & \square\end{array}$

The user's manual is available and consists of NBS Spec. Publ. 400-75, NBSIR 83-2779, and NBSIR 85-3292 


\section{INSTRUCTIONS}

01. Summary Date. Enter date summary prepared. Use Year, Month, Day format: YYMMDD.

02. Summary Prepared By. Enter name and phone number (including area code) of individual who prepared this summary.

03. Summary Action. Mark the appropriate box for new summary, replacement summary or deletion of summary. If this software summary is a replace. ment, enter under "Prevlous Internal Software 1D" the internal software Identificatlon as reported In Item 07 of the original summary, and enter the new internal software identification In Item 07 of this form; compiete all other items as for a new summary. If a software summary is to be deleted, enter under "Previous Internal Software 10 " the Internal software Identification as reported in item 07 of the original summary; complete only Items $01,02,03$ and 11 on this form.

04. Software Date. Enter date software was completed or last updated. Use Year, Month, Day format: YYMMDD.

05. Software Title. Make title as descriptive as possible.

06. Short Title. (Optional) Enter commonly used abbreviation or acronym which identifies the software.

07. Internal Software ID. Enter a unique identification number or code.

08. Software Type. Mark the appropriate box for an Automated Data System (set of computer programs), Computer Program, or Subroutine/Module, whichever best describes the software.

09. Processing Mode. Mark the appropriate box for an Interactive, Batch, or Combination mode, whichever best describes the software.

10. Application Area.

General: Mark the appropriate box which best describes the general area of application from among:

Computer Systems Support/Utility Process Control

Management/Business Bibliographlc/Textua

Scientific/Engineering Other

Specific: Specify the sub-area of application; e.g.: "COBOL optimizer" if the general area is "Computer Systems Support/Utility": "Payroll" if the general area Is "Management/Business"; etc. Elaborate here if the general area is "Other."

11. Submitting Organization and Address. Identify the organization responsible for the software as completely as possible, to the Branch or Division level, but including Agency, Department (Bureau/Administration), Service, Corporation, Commission, or Council. Fill in complete mailing address, including mail code, street address, city, state, and ZIP code.

12. Technical Contact(s) and Phone: Enter person(s) or office(s) to be contacted for technical Information on subject matter and/or operational aspects of software. Include telephone area code. Provide organization name and malling address, if different from that in item 11.

13. Narrative. Describe concisely the problem addressed and methods of solution. Include significant factors such as speclal operating system modlfi. cations, security concerns, relationships to other software, input and output media, virtual memory requirements, and unlque hardware features. Cite references, if approprlate.

14. Keywords. List significant words or phrases which reflect the functions, applications and features of the software. Separate entries with semicoions.

15. Computer Manufacturer and Model. Identify mainframe computer(s) on whicli suftware is operatlonal.

16. Computer Operating System. Enter name, number, and release under which software Is operating. Identify enhancements In the Narrative (item 13).

17. Programing Language(s). Identify the language(s) in which the software is written, including version; e.g., ANSI COBOL, FORTRAN V, SIMSCRIPT II.5, SLEUTH II.

18. Number of Source Program Statements. Include statements in this software, stparate macros, called subroutines, etc.

19. Computer Memory Requirements. Enter minimum internal memory necessary to execute software, exclusive of memory required for the operating system. Specify words, bytes, characters, etc., and number of bits per unit. Identify virtual memory requirements in the Narrative (item 13).

20. Tape Drives. Identify number needed to operate software. Speclfy, if criticai, manufacturer, model, tracks, recording density, etc.

21. DIsk/Drum Units. Identlfy number and slze (in same unlts as "Memory"-item 19) needed to operate software. Specify, If critical, manufacturer, model, etc.

22. Terminals. Identlfy number of terminals required. Specify, If critlcal, type, speed, character set, screen/line slze, etc.

23 Other Operational Requirements. Identify peripheral devices, support software, ur related equipment not Indicated above, e.g., optical character devices, facsimile, computer-output microflim, graphic plotters.

24. Software Availability. Mark the approprlate box whlch best descrlbes the software availability from among: Avallable to the Publlc, Llmited Availablitty (e.g.: for government use only), and For-In-house Use Only. If the software is "Available", Include a mail or phone contact point, as well as the price and form in which the software is available, if possible.

25. Documentation Availabllity. Mark the approprlate box which best describes the documentation availability from among: Available to the Public, In adequate for Distribution, and For In-house Use Only. If documentation Is "Available", Include a mail or phone contact polnt, as well as the price and form in which the documentation is available, if possible. If documentation is presently "Inadequate", show the expected availability date.

26. For Submitting Organlzation Use. This area is provlded for the use of the organization submitting this summary. It may contaln any Information deemed useful for Internal operation. 

